\title{
Veterinarian barriers to knowledge translation (KT) within the context of swine infectious disease research: an international survey of swine veterinarians
}

Sheila Keay ${ }^{1 *}\left(\mathbb{D}\right.$, Jan M. Sargeant ${ }^{1,2}$, Annette O'Connor $^{3}$, Robert Friendship ${ }^{1}$, Terri O'Sullivan ${ }^{1}$ and Zvonimir Poljak ${ }^{1}$

\begin{abstract}
Background: Food animal veterinarians face commodity specific and urgent global challenges yet conditions preventing use of best available knowledge have been sparsely studied. The American Association of Swine Veterinarians (AASV) membership ( $N=1289$ ) was surveyed online to benchmark their information priorities and their motivations and sources for keeping current with infectious disease research, and to describe their reported time, skill, access, and process as barriers to knowledge translation (KT).

Results: Respondents $(n=80)$ were mostly from Canada $(n=40)$ and the U.S.A $(n=31)$ and demographics approximated the AASV's. Colleagues are the first choice for information on difficult cases (49\%, 95\%Cl: 38-61). Half of respondents $(53 \%, 95 \% \mathrm{Cl}$ : 41-64) spend an hour or less per week keeping up with infectious disease research. The majority reported moderate or less than moderate efficiency (62\%,95\%Cl: $51-72)$, and moderate or greater stress (59\%, 95\% Cl: 48-70) with their process for keeping up. Journal article methods sections are commonly not read, almost a third (32\%, 95\% Cl: 22-43) reported either they do not evaluate statistical methods or that they had poor confidence to do so, and half (52,95\%Cl: 41-63) could not explain 'confounding bias'. Approximately half (55\%, 95\%Cl: 41-69) with direct oversight of swine herds had full access to 2 or fewer academic journals. Approximately a third of respondents (34\%,95\% Cl: $24-46)$ selected only formats involving single research studies (either full text or summaries) as preferred reading materials for keeping current over expert summaries of the body of evidence.
\end{abstract}

* Correspondence: skeay@uoguelph.ca

'Department of Population Medicine, Ontario Veterinary College, University of Guelph, Guelph, Canada

Full list of author information is available at the end of the article

(c) The Author(s). 2020 Open Access This article is licensed under a Creative Commons Attribution 4.0 International License, which permits use, sharing, adaptation, distribution and reproduction in any medium or format, as long as you give appropriate credit to the original author(s) and the source, provide a link to the Creative Commons licence, and indicate if changes were made. The images or other third party material in this article are included in the article's Creative Commons licence, unless indicated otherwise in a credit line to the material. If material is not included in the article's Creative Commons licence and your intended use is not permitted by statutory regulation or exceeds the permitted use, you will need to obtain permission directly from the copyright holder. To view a copy of this licence, visit http://creativecommons.org/licenses/by/4.0/ The Creative Commons Public Domain Dedication waiver (http://creativecommons.org/publicdomain/zero/1.0/) applies to the data made available in this article, unless otherwise stated in a credit line to the data. 


\begin{abstract}
(Continued from previous page)
Conclusion: KT barriers are considerable and a source of stress for many swine veterinarians. Sub-optimal efficiency with keeping up and low confidence to appraise aspects of research are concerns. Results are consistent with previous literature and illustrate need for improved KT infrastructure and for additional training in statistical methods and interpretation of primary research. Further evaluation is warranted of why approximately a third of veterinarians in this study, for the purpose of keeping up, preferentially choose to review individual research studies over choices that would include an expert summary of the body of evidence. Consideration of reasons for this preference will be important in the planning of $K T$ infrastructure improvements.
\end{abstract}

Keywords: Knowledge translation, Veterinarian, Swine infectious disease, Survey, Questionnaire, Research synthesis, Evidence based medicine, Information sources

\section{Background}

\section{Evidence based medicine (EBM), knowledge translation} (KT) and barriers to KT

Within health professions, evidence based medicine (EBM) was described by Sackett [1] as the integration of individual clinical expertise with the best available external body of evidence. Within an EBM framework, putting knowledge to use is referred to as knowledge translation (KT) [2]. Both tacit and explicit knowledge are needed for the practice of EBM [1]. Explicit knowledge relates to methodological rigor whereas tacit knowledge is related to "relevance or real-world viability" [3, 4]. For the purposes of this report, peer-reviewed primary research literature was considered exclusively as explicit knowledge.

Knowledge translation (KT) includes the iterative processes of synthesis, dissemination, exchange, and application of knowledge [5]. Barriers, or the factors which impede knowledge translation, vary in type and impact depending on the type of knowledge [4], the directional flow of information, and the population level or levels being investigated [6, 7]. Time, access, and skill, identified as individual level KT barriers [8-10], have been sparsely studied in veterinary medicine [11-13]. We consider also process as a fourth barrier, or the sequential steps taken from wanting current research information through to its assimilation into practice.

\section{Veterinarian KT surveys}

Veterinary access to information has significantly changed since the 1990's. Surveys exploring veterinarian KT barriers or continuing education and continuing professional development (CE/CPD) prior to this time may therefore have limited applicability. Additionally, species specialization influences $\mathrm{CE} / \mathrm{CPD}$ learning priorities. The role of food animal and agri-food public health veterinarians includes also protection of the quality, security, and sustainability of food for human consumption $[14,15]$, and they prefer topics of preventive and population medicine [16-18]. As such, modern applied food animal research is often population focused, publicly funded, and global in applicability, making it distinct from other areas of veterinary research [19-22].

\section{Swine veterinarians and $\mathrm{KT}$}

Swine veterinarians are a specialized, progressive, and cohesive community of practice [23]. On-going emergence and re-emergence of swine diseases of economic and potentially public health significance [24, 25], have made for heightened, dynamic, and sometimes urgent KT needs [26]. Three published surveys focus specifically on swine veterinarians; Penny and Penny [27] (1978) identified pig research priorities and summarized gaps between swine veterinarian interests and available research, a Dutch language survey by Maes (2010) [28], focused on Belgian demographics and practice functioning, and a 2010 survey of Ontario swine industry stakeholders, inclusive of swine veterinarians, showed veterinarians had a preference for producer meetings as a source of educational material [29].

\section{Survey objectives}

The survey objectives were to benchmark swine veterinarian overall priority interests, their motivations for seeking, and their sources used to find research information, and to describe how time, process, access, and skill to understand and to assess research (hereafter referred to as skill), may act as barriers to keeping current with infectious disease research.

\section{Results}

\section{Survey respondent metrics}

Ninety-four respondents opened the online link, 10 exited at the consent page, 1 answered only first block questions, 2 identified as non-veterinarians, and 1 omitted to identify role, leaving 80 usable responses. Response rate was just over 6\% (83/1289) of AASV membership; however, approximately $29 \%$ of the CASV membership participated (M. DeGroot, personal communication).

\section{Demographics}

Respondent demographics are detailed in Table 1 in Additional file 3. By veterinary role, composition closely 
matched that of the AASV membership (see Fig. 1 in Additional file 3). Overall, most respondents worked either in Canada $(50 \%, n=40)$ or the U.S.A. (39\%, $n=31)$, most were experienced, with two thirds $(64 \%$, $n=51$ ) reporting more than 15 years of working with swine, and half $(51 \%, n=41)$ working exclusively with swine. Eleven percent $(n=9)$ provided direct oversight to greater than 100,000 sows worth of production each $(100,000$ sows translates into approximately 2 million market offspring/year). Two demographic criteria were used to dichotomize respondent's role as 'direct' $(n=47)$ or 'indirect' $(n=32)$ (See Table 2A and $\mathrm{B}$ in Additional file 3). Most of the respondents designated as 'indirect' also reported zero (0) sows worth of production under their veterinary care $(86 \%$, $n=28$ ) (See Table 2D in Additional file 3).

\section{Swine veterinarian priority interests}

Respondents most sought information on disease control, emerging diseases, and disease control interventions, inclusive of globally endemic production viruses (PRRS, IAV-S, PED), and bacteria (M. hyopneumoniae, L. intracellularis, S. suis) (Table 1). Veterinarians with indirect oversight were almost 4 times as likely to select antimicrobial resistance as one of their top three interests compared with veterinarians with direct oversight (prevalence ratio $(\mathrm{PR})=3.9,95 \% \mathrm{CI}: 1.1-13.7, p=0.04$ ). Those with direct field oversight were 3 times as likely to select antimicrobials $(\mathrm{PR}=2.9,95 \% \mathrm{CI}: 1.2-6.8, p=$ 0.008 ) as one of their top three interests, 3 times as likely to include Haemophilus parasuis amongst their top three swine bacteria of interest $(\mathrm{PR}=2.9,95 \% \mathrm{CI}$ : 1.07-7.80, $p=0.02$ ), and also more likely to select IAV-S as a priority virus $(\mathrm{PR}=1.6,95 \% \mathrm{CI}: 1.08-2.30, p=0.01)$ versus veterinarians with indirect oversight.

\section{Motivation to seek infectious disease information}

Difficult cases most motivated veterinarians with direct oversight to seek information (Table 2) and were three times as likely to be a motivator for direct versus indirect veterinarians ( $\mathrm{PR}=3.1,95 \% \mathrm{CI}: 1.4-6.6, p<0.01)$. Veterinarians with indirect oversight were over 6 times as likely to be motivated by other work requirements versus direct veterinarians $(\mathrm{PR}=6.2,95 \% \mathrm{CI}: 2.3-16.8, p<0.01)$.

\section{Barriers to knowledge translation \\ Time}

About half of all respondents (53\%, 95\% CI: 41-64) spend $1 \mathrm{~h}$ or less per week keeping current or reviewing infectious disease research information (Table 2). Veterinarians with indirect oversight were 3 times as likely as those with direct oversight to spend greater than $3 \mathrm{~h}$ per week at this task (PR $=3.0,95 \% \mathrm{CI}: 1.0-9.2, p=0.05)$.

\section{Process}

Respondents described, on a scale from 1 to 5 , their level of efficiency and their level of stress with the process of keeping up with infectious disease research. More than half of all respondents rated their level of stress and their level of efficiency, at best, as moderate (Table 2). When outcomes were collapsed into dichotomous responses respondents reporting 'high to complete efficiency' versus 'moderate to no efficiency', were 1.8 times more likely to also report spending greater than an hour per week keeping current ( $\mathrm{PR}=1.8,95 \% \mathrm{CI}: 1.2-2.9, p=0.02)$, and more likely to report having confidence to assess statistical methods ( $\mathrm{PR}=$ 1.4, 95\%CI: 1.1-1.9, $p=0.03)$. Stress and efficiency were reciprocally associated. Respondents reporting the lowest levels of stress were more than twice as likely to also report the highest levels of efficiency ( $\mathrm{PR}=2.2,95 \% \mathrm{CI}: 1.3-4.0$, $p=0.01$ ). Those motivated by difficult cases to seek information were more than twice as likely to also report the highest levels of stress ( $\mathrm{PR}=2.2,95 \% \mathrm{CI} 1.1-4.5, p=0.04)$. Respondent reported levels of stress and efficiency did not differ by role (see Table 3 in Additional file 3).

\section{Skill}

Familiarity with knowledge terms Respondents were asked to describe their level of understanding of each knowledge term as 'can explain', 'have heard of', or as 'not familiar with' (see Table 4 in Additional file 3). Consistency of self-reported levels of understanding, as measured by Cronbach's alpha, was poor for the grouping of vaccine terms (efficacy, effectiveness, and basic reproductive number) (Cronbach's alpha $=0.54$ ) and for the grouping of EBM terms (EBM, EBVM, and evidence pyramid) (Cronbach's alpha $=0.69$ ), but was strong for the grouping of bias terms (information, selection, and confounding bias) (Cronbach's alpha $=0.91)$. Veterinarians with indirect oversight were twice as likely versus veterinarians with direct oversight to report not having heard of the term evidence pyramid $(\mathrm{PR}=2.2$, 95\%CI: 1.2-4.1, $p=0.02)$. When responses were dichotomized as either 'can explain' or as 'cannot explain' (Table 3), ability to explain was strongest for the terms vaccine efficacy and vaccine effectiveness, and poorest for the terms evidence pyramid, basic reproductive number, and confounding and information biases.

Confidence to assess technical aspects of a research study Respondents were asked to describe their level of confidence to evaluate the appropriateness of study designs used, the statistical methods used, and study author's statistical interpretation of findings. Internal consistency of responses was good (Cronbach's alpha $=0.89$ ) and the majority of respondents, regardless of role, reported having 'some confidence' to evaluate each of the three aspects of a study (Fig. 1). 
Table 1 Respondent selections, by veterinary role, of general topics (Q1), swine viruses (Q2), and swine bacteria (Q3), for which information is most often sought ${ }^{\mp}$. Respondents could select up to three [3] choices per question

\begin{tabular}{|c|c|c|c|c|c|c|c|}
\hline & & \multicolumn{2}{|c|}{$\begin{array}{l}\text { Indirect } \\
\text { Oversight }\end{array}$} & \multicolumn{2}{|c|}{$\begin{array}{l}\text { Direct } \\
\text { Oversighttt }\end{array}$} & \multicolumn{2}{|c|}{ Overall } \\
\hline & & $\%$ & $95 \% \mathrm{Cl}$ & $\%$ & $95 \% \mathrm{Cl}$ & $\%$ & $95 \% \mathrm{Cl}$ \\
\hline Q1- Topics of interest & $\mathrm{N}=79$ & & & & & & \\
\hline Welfare & Yes $(n=10)$ & 16 & {$[7,33]$} & 11 & {$[4,23]$} & 13 & {$[7,22]$} \\
\hline Antimicrobial resistance & Yes $(n=11)$ & 25 & {$[13,43]$} & 6 & {$[2,18]$} & 14 & {$[8,24]$} \\
\hline Environment & Yes $(n=3)$ & 0 & & 6 & {$[2,18]$} & 4 & {$[1,11]$} \\
\hline Reproduction & Yes $(n=15)$ & 9 & {$[3,26]$} & 26 & {$[15,40]$} & 19 & {$[12,29]$} \\
\hline Biosecurity & Yes $(n=13)$ & 9 & {$[3,26]$} & 21 & {$[12,36]$} & 16 & {$[10,27]$} \\
\hline Nutrition & Yes $(n=3)$ & 0 & & 6 & {$[2,18]$} & 4 & {$[1,11]$} \\
\hline Vaccines & Yes $(n=26)$ & 41 & {$[25,58]$} & 28 & {$[17,42]$} & 33 & {$[23,44]$} \\
\hline Antibiotics and therapeutics & Yes $(n=26)$ & 16 & {$[7,33]$} & 45 & {$[31,59]$} & 33 & {$[23,44]$} \\
\hline Genetics & Yes $(n=0)$ & 0 & & 0 & & 0 & \\
\hline Disinfectants & Yes $(n=1)$ & 0 & & 2 & {$[0,14]$} & 1 & {$[0,9]$} \\
\hline Emerging diseases & Yes $(n=52)$ & 75 & {$[57,87]$} & 60 & {$[45,73]$} & 66 & {$[54,76]$} \\
\hline Disease control & Yes $(n=57)$ & 59 & {$[42,75]$} & 81 & {$[67,90]$} & 72 & {$[61,81]$} \\
\hline Zoonoses & Yes $(n=4)$ & 9 & {$[3,26]$} & 2 & {$[0,14]$} & 5 & {$[2,13]$} \\
\hline Other & Yes $(n=6)$ & 13 & {$[5,29]$} & 4 & {$[1,16]$} & 8 & {$[3,16]$} \\
\hline Q2-Viruses of interest & $\mathrm{N}=79$ & & & & & & \\
\hline African Swine Fever* & Yes $(n=0)$ & 0 & & 0 & & 0 & \\
\hline Foot and mouth disease & Yes $(n=0)$ & 0 & & 0 & & 0 & \\
\hline Classical Swine Fever & Yes $(n=4)$ & 6 & {$[2,22]$} & 4 & {$[1,16]$} & 5 & {$[2,13]$} \\
\hline Influenza A & Yes $(n=53)$ & 50 & {$[33,67]$} & 79 & {$[64,88]$} & 67 & {$[56,77]$} \\
\hline Porcine circovirus type 2 & Yes $(n=29)$ & 31 & {$[17,49]$} & 40 & {$[27,55]$} & 37 & {$[27,48]$} \\
\hline Porcine epidemic diarrhea virus & Yes $(n=52)$ & 78 & {$[60,89]$} & 57 & {$[43,71]$} & 66 & {$[54,76]$} \\
\hline PRRS & Yes $(n=65)$ & 75 & {$[57,87]$} & 87 & {$[74,94]$} & 82 & {$[72,89]$} \\
\hline Pseudorabies & Yes $(n=1)$ & 3 & {$[0,20]$} & 1 & {$[0,9]$} & 1 & {$[0,9]$} \\
\hline Senecavirus A & Yes $(n=14)$ & 25 & {$[13,43]$} & 13 & {$[6,26]$} & 18 & {$[11,28]$} \\
\hline Porcine rotavirus & Yes $(n=8)$ & 6 & {$[2,22]$} & 13 & {$[6,26]$} & 10 & {$[5,19]$} \\
\hline Other & Yes $(n=0)$ & & & & & & \\
\hline Q3-Bacteria of interest & $\mathrm{N}=79$ & & & & & & \\
\hline Actinobacillus pleuropneumoniae & Yes $(n=14)$ & 19 & {$[9,36]$} & 17 & {$[9,31]$} & 18 & {$[11,28]$} \\
\hline Brachyspira hyodysenteriae & Yes $(n=16)$ & 19 & {$[9,36]$} & 21 & {$[12,36]$} & 20 & {$[13,31]$} \\
\hline Escherichia coli & Yes $(n=28)$ & 41 & {$[25,58]$} & 32 & {$[20,47]$} & 35 & {$[26,47]$} \\
\hline Haemophillus parasuis & Yes $(n=21)$ & 13 & {$[5,29]$} & 36 & {$[24,51]$} & 27 & {$[18,38]$} \\
\hline Lawsonia intracellularis & Yes $(n=34)$ & 38 & {$[22,55]$} & 47 & {$[33,61]$} & 43 & {$[32,54]$} \\
\hline Mycoplasma hyopneumoniae & Yes $(n=48)$ & 59 & {$[42,75]$} & 62 & {$[47,75]$} & 61 & {$[49,71]$} \\
\hline Salmonella & Yes $(n=26)$ & 34 & {$[20,52]$} & 32 & {$[20,47]$} & 33 & {$[23,44]$} \\
\hline Streptococcus suis & Yes $(n=31)$ & 47 & {$[30,64]$} & 34 & {$[22,49]$} & 39 & {$[29,51]$} \\
\hline Other & Yes $(n=4)$ & 0 & & 9 & {$[3,21]$} & 5 & {$[2,13]$} \\
\hline
\end{tabular}

† Indirect oversight $=$ non-practitioner that provides 1000 sows worth or less with direct veterinary services

t+ Direct oversight $=$ practitioner or a non-practitioner that provides $>1000$ sows worth with direct veterinary services

* Note, African Swine Fever had not yet been diagnosed in Asia at the time of this survey

$\mp$ Cells are color conditioned on blue to white with higher percentages as darkest blue

When response options were dichotomously aggregated approximately a quarter $(26 \%, 95 \% \mathrm{CI}: 17-37)$ of respondents reported 'no confidence to evaluate/do not evaluate' the statistical interpretation of findings, and almost a third (32\%, 95\%CI: 22-43) reported 'no confidence to evaluate/do not evaluate' the statistical 
Table 2 Frequency ${ }^{\mp}$ of self-reported top motivation for seeking information(Q6) average time spent per week (Q7), process efficiency (Q8), and level of stress (Q9) with staying current with swine infectious disease research, by veterinary role

\begin{tabular}{|c|c|c|c|c|c|c|}
\hline & \multicolumn{2}{|c|}{ Indirect Oversight +} & \multicolumn{2}{|c|}{ Direct Oversightt† } & \multicolumn{2}{|c|}{ Overall } \\
\hline & $\%$ & $95 \% \mathrm{Cl}$ & $\%$ & $95 \% \mathrm{Cl}$ & $\%$ & $95 \% \mathrm{Cl}$ \\
\hline \multicolumn{7}{|c|}{ Q6-Top motivation for seeking infectious disease research information } \\
\hline Other work requirement $(n=21)$ & 53 & {$[36,70]$} & 9 & {$[3,21]$} & 27 & {$[18,38]$} \\
\hline Difficult case-with diagnosis $(n=18)$ & 9 & {$[3,26]$} & 32 & {$[20,47]$} & 23 & {$[15,34]$} \\
\hline Difficult case-no diagnosis ( $n=15)$ & 9 & {$[3,26]$} & 26 & {$[15,40]$} & 19 & {$[12,29]$} \\
\hline Emerging disease awareness ( $n=15)$ & 28 & {$[15,46]$} & 13 & {$[6,26]$} & 19 & {$[12,29]$} \\
\hline General Interest $(n=10)$ & 0 & & 21 & {$[12,36]$} & 13 & {$[7,22]$} \\
\hline Total $(n=79)$ & 100 & & 100 & & 100 & \\
\hline \multicolumn{7}{|c|}{ Q7-Time spent on average per week to keep current with infectious disease research information } \\
\hline$>0-30$ minutes $(n=17)$ & 26 & {$[13,44]$} & 19 & {$[10,33]$} & 22 & {$[14,33]$} \\
\hline$>30$ minutes -1 hour $(n=24)$ & 26 & {$[13,44]$} & 34 & {$[22,49]$} & 31 & {$[21,42]$} \\
\hline$>1$ hour -3 hours $(n=25)$ & 23 & {$[11,41]$} & 38 & {$[25,53]$} & 32 & {$[22,43]$} \\
\hline$>3$ hours $(n=12)$ & 26 & {$[13,44]$} & 9 & {$[3,21]$} & 15 & {$[9,25]$} \\
\hline Total $(n=78)$ & 100 & & 100 & & 100 & \\
\hline \multicolumn{7}{|c|}{ Q8-Level of efficiency with process to stay current ( $1=$ highest, $5=$ lowest $)$} \\
\hline 1 Complete efficiency $(n=1)$ & 0 & & 2 & {$[0,14]$} & 1 & {$[0,9]$} \\
\hline $2(n=29)$ & 38 & {$[22,55]$} & 36 & {$[24,51]$} & 37 & {$[27,48]$} \\
\hline $3(n=23)$ & 28 & {$[15,46]$} & 30 & {$[18,45]$} & 29 & {$[20,40]$} \\
\hline $4(n=21)$ & 31 & {$[17,49]$} & 23 & {$[13,38]$} & 27 & {$[18,38]$} \\
\hline 5 No efficiency $(n=5)$ & 3 & {$[0,20]$} & 9 & {$[3,21]$} & 6 & {$[3,15]$} \\
\hline Total $(n=79)$ & 100 & & 100 & & 100 & \\
\hline \multicolumn{7}{|c|}{ Q9-Level of stress with process of staying current (1 = highest, $5=$ lowest) } \\
\hline 1 No stress ( $n=1$ ) & 16 & {$[7,33]$} & 26 & {$[15,40]$} & 22 & {$[14,32]$} \\
\hline $2(n=15)$ & 22 & {$[11,40]$} & 17 & {$[9,31]$} & 19 & {$[12,29]$} \\
\hline $3(n=24)$ & 28 & {$[15,46]$} & 32 & {$[20,47]$} & 30 & {$[21,42]$} \\
\hline $4(n=19)$ & 22 & {$[11,40]$} & 26 & {$[15,40]$} & 24 & {$[16,35]$} \\
\hline 5 Completely stressful $(n=4)$ & 13 & {$[5,29]$} & 0 & & 5 & {$[2,13]$} \\
\hline Total $(n=79)$ & 100 & & 100 & & 100 & \\
\hline
\end{tabular}

$\dagger$ Indirect oversight $=$ non-practitioner that provides 1000 sows worth or less with direct veterinary services

†† Direct oversight $=$ practitioner or a non-practitioner that provides $>1000$ sows worth with direct veterinary services

$\mp$ Cells are color conditioned on blue to white with higher percentages as darkest blue

methods used (see Table 6A in Additional file 3). Direct veterinarians were almost twice as likely versus indirect veterinarians to report 'no confidence to evaluate/do not evaluate' the statistical methods used ( $\mathrm{PR}=1.8,95 \% \mathrm{CI}$ : $1.1-2.8, p=0.01)$. Confidence to evaluate technical aspects of studies was not significantly associated with frequency of reading methods sections of articles (See Table 6B in Additional file 3).

Consistency in the reported confidence to assess the technical aspects of a study with reported levels of understanding of each of the terms 'confounding bias', 'information bias', and 'selection bias' was good (Cronbach's alpha $=0.84$, 0.84 , and 0.83 respectively). Respondents who reported being unable to explain confounding bias, versus those who could, were 2.8 times more likely to also report 'no confidence/do not assess' the statistical interpretation of study findings ( $\mathrm{PR}=2.78,95 \% \mathrm{CI}: 1.1-6.9, p=0.02)$.

Access

Ranking of 1st, 2nd and 3rd choices for information on difficult cases Overall, colleagues were the most 
Table 3 (Q10) Frequency ${ }^{\mp}$ of self-reported level of familiarity with epidemiologic and EBM terminology with outcomes dichotomized* as 'can explain' or 'cannot explain', by veterinary role

\begin{tabular}{|c|c|c|c|c|c|c|}
\hline & \multicolumn{2}{|c|}{ Indirect Oversight ${ }^{\dagger}$} & \multicolumn{2}{|c|}{ Direct Oversightt+ } & \multicolumn{2}{|c|}{ Overall } \\
\hline & $\%$ & $95 \% \mathrm{Cl}$ & $\%$ & $95 \% \mathrm{Cl}$ & $\%$ & $95 \% \mathrm{Cl}$ \\
\hline \multicolumn{7}{|c|}{ Evidence based medicine (EBM) $n=79$} \\
\hline Can explain ( $n=56)$ & 72 & {$[54,85]$} & 70 & {$[55,82]$} & 71 & {$[60,80]$} \\
\hline Cannot explain $(n=23)$ & 28 & {$[15,46]$} & 30 & {$[18,45]$} & 29 & {$[20,40]$} \\
\hline \multicolumn{7}{|c|}{ Evidence-based veterinary medicine (EBVM) $n=79$} \\
\hline Can explain ( $n=57)$ & 69 & {$[51,83]$} & 74 & {$[60,85]$} & 72 & {$[61,81]$} \\
\hline Cannot explain $(n=22)$ & 31 & {$[17,49]$} & 26 & {$[15,40]$} & 28 & {$[19,39]$} \\
\hline \multicolumn{7}{|l|}{ Systematic review $\mathrm{n}=79$} \\
\hline Can explain ( $n=47)$ & 59 & {$[42,75]$} & 60 & {$[45,73]$} & 59 & {$[48,70]$} \\
\hline Cannot explain $(n=32)$ & 41 & {$[25,58]$} & 40 & {$[27,55]$} & 41 & {$[30,52]$} \\
\hline \multicolumn{7}{|l|}{ Meta-analysis $n=79$} \\
\hline Can explain $(n=46)$ & 66 & {$[48,80]$} & 53 & {$[39,67]$} & 58 & {$[47,69]$} \\
\hline Cannot explain $(n=33)$ & 34 & {$[20,52]$} & 47 & {$[33,61]$} & 42 & {$[31,53]$} \\
\hline \multicolumn{7}{|l|}{ Evidence pyramid $n=78$} \\
\hline Can explain ( $n=16)$ & 19 & {$[9,36]$} & 22 & {$[12,36]$} & 21 & {$[13,31]$} \\
\hline Cannot explain $(n=62)$ & 81 & {$[64,91]$} & 78 & {$[64,88]$} & 79 & {$[69,87]$} \\
\hline \multicolumn{7}{|l|}{ Selection bias $n=79$} \\
\hline Can explain ( $n=47)$ & 66 & {$[48,80]$} & 55 & {$[41,69]$} & 59 & {$[48,70]$} \\
\hline Cannot explain $(n=32)$ & 34 & {$[20,52]$} & 45 & {$[31,59]$} & 41 & {$[30,52]$} \\
\hline \multicolumn{7}{|l|}{ Information bias $n=79$} \\
\hline Can explain ( $n=39)$ & 56 & {$[39,72]$} & 45 & {$[31,59]$} & 49 & {$[38,60]$} \\
\hline Cannot explain $(n=40)$ & 44 & {$[28,61]$} & 55 & {$[41,69]$} & 51 & {$[40,62]$} \\
\hline \multicolumn{7}{|l|}{ Confounding bias $n=79$} \\
\hline Can explain ( $n=38)$ & 53 & {$[36,70]$} & 45 & {$[31,59]$} & 48 & {$[37,59]$} \\
\hline Cannot explain $(n=41)$ & 47 & {$[30,64]$} & 55 & {$[41,69]$} & 52 & {$[41,63]$} \\
\hline \multicolumn{7}{|l|}{ Risk ratio $\mathrm{n}=79$} \\
\hline Can explain $(n=45)$ & 63 & {$[45,78]$} & 53 & {$[39,67]$} & 57 & {$[46,68]$} \\
\hline Cannot explain $(n=34)$ & 38 & {$[22,55]$} & 47 & {$[33,61]$} & 43 & {$[32,54]$} \\
\hline \multicolumn{7}{|l|}{ Vaccine efficacy $n=79$} \\
\hline Can explain $(n=69)$ & 84 & {$[67,93]$} & 89 & {$[77,96]$} & 87 & {$[78,93]$} \\
\hline Cannot explain $(n=10)$ & 16 & {$[7,33]$} & 11 & {$[4,23]$} & 13 & {$[7,22]$} \\
\hline \multicolumn{7}{|c|}{ Vaccine effectiveness $n=79$} \\
\hline Can explain ( $n=60)$ & 72 & {$[54,85]$} & 79 & {$[64,88]$} & 76 & {$[65,84]$} \\
\hline Cannot explain $(n=19)$ & 28 & {$[15,46]$} & 21 & {$[12,36]$} & 24 & {$[16,35]$} \\
\hline \multicolumn{7}{|c|}{ Basic reproduction number [R0] $\mathrm{n}=79$} \\
\hline Can explain $(n=30)$ & 47 & {$[30,64]$} & 32 & {$[20,47]$} & 38 & {$[28,49]$} \\
\hline Cannot explain $(n=49)$ & 53 & {$[36,70]$} & 68 & {$[53,80]$} & 62 & {$[51,72]$} \\
\hline Total & 100 & & 100 & & 100 & \\
\hline
\end{tabular}

* See Table 2 in Additional file 3 for details on how categories were collapsed into dichotomous options

+ Indirect oversight $=$ non-practitioner that provides 1000 sows worth or less with direct veterinary services

t† Direct oversight $=$ practitioner or a non-practitioner that provides $>1000$ sows worth with direct veterinary services

F Cells with \% responses for "Cannot explain" are color conditioned on blue to white with higher percentages as darkest blue

frequently selected first choice for seeking information on difficult cases (49\%, 95\%CI: 38-61), scientific journals as the second choice $(26 \%, 95 \% \mathrm{CI}: 17-38)$, and conference proceedings as the third choice $(17 \%, 95 \% \mathrm{CI}$ : $10-$ 28) (Fig. 2). The respondents' ordering of rankings was varied and included 60 different combinations of the three choices with colleague-specialist-journals being the most frequent ordering (5\%).Veterinarians with direct oversight were 1.7 times more likely (95\% CI: 1.0-2.9, $p=0.04)$ to select colleagues as a first choice, and were 2.1 times as likely to have picked proceedings as one of a 1st, 2nd, or 3rd choice (95\%CI: 1.0-4.8, $p=0.05$ ), 


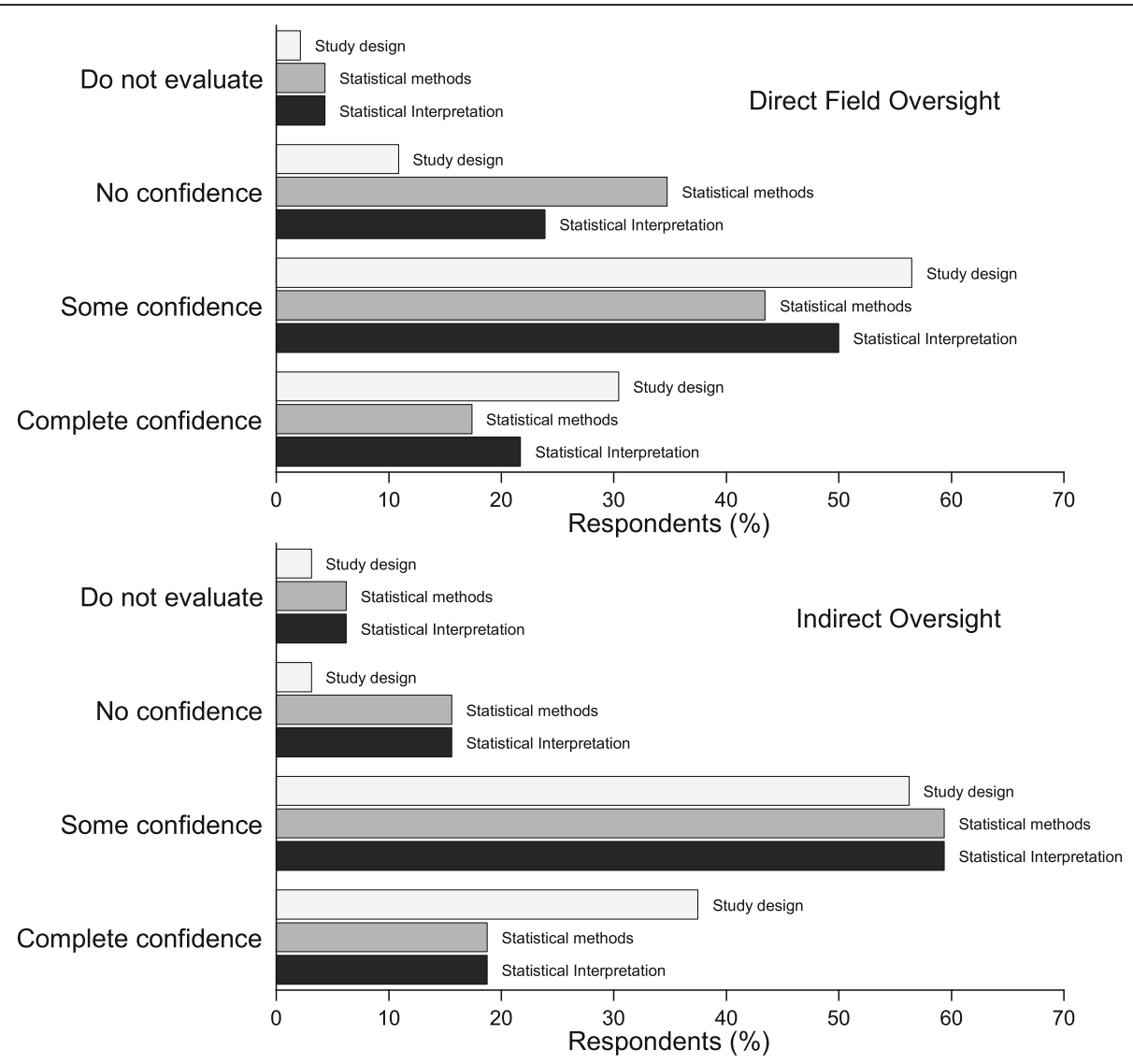

Fig. 1 (Q12) Self-reported confidence to evaluate a research paper for the appropriateness of the study design used, the statistical methods used, and the author's statistical interpretation of results, by role (direct vs. indirect) (Data supporting this figure are shown in Table 5 in Additional file 3)

versus indirect veterinarians, whereas indirect veterinarians were 4.5 times more likely to select scientific journals as a first choice $(95 \% \mathrm{CI}: 1.3-15.1, p=0.01)$ versus direct veterinarians.

Journal reading habits The most frequently read sections of scientific journal articles were the abstract (97\%, 95\%CI: 90-99) and conclusions (86\%, 95\%CI: 76-92), followed by results $(73 \%, 95 \% \mathrm{CI}: 62-82)$ and the discussion (7\%0, 95\%CI: 58-79) (Fig. 3). Less than half of respondents usually read the methods $(42 \%, 95 \% \mathrm{CI}$ : $32-$ 54). There were no significant differences by role in the frequency of 'usually read' versus 'not usually read' sections.

Use of search methods Respondents were asked to select their two most preferred methods to search for swine infectious disease research information from a list of 6 options. Online options were preferred with the online AASV Information Library (61\%, 95\%CI: 49-71), followed by Google or Google Scholar (52\%, 95\%CI: 41$63)$, and bibliographic databases (51\%, 95\%CI: 40-62) as most frequently selected (Table 4). The AASV library, available online to AASV members only, provides access to conference proceedings from 8 national and international swine meetings, to the Journal of Swine Health and Production (JSHAP), and to a PDF of the textbook Diseases of Swine. Seventy-four percent of veterinarians with direct field oversight (95\%CI: 60-85) most preferred the AASV library and were 1.8 times more likely to do so over veterinarians with indirect oversight $(\mathrm{PR}=$ 1.83, 95\%CI: $1.16-2.89, p=0.004)$. There were no other significant differences by role in choice of preferred methods for searching for research information.

Use of journals Respondents were asked to identify up to three journals they used most for swine infectious disease information. The list of provided options captured all but $10 \%$ (95\%CI: $5-19)$ of the respondent selections (Table 4). The AASV publication JSHAP was selected most (89\%, 95\%CI: 79-94), followed by the Canadian (30\%, 95\%CI: 21-42), and the American (18\%, 95\%CI: 11-28) Veterinary Association Journals, each of which is freely available with membership. Forty-one percent (95\%CI: 30-52) reported access to greater than 6 scientific journals versus 35\% (95\%CI: 41-69) reporting 

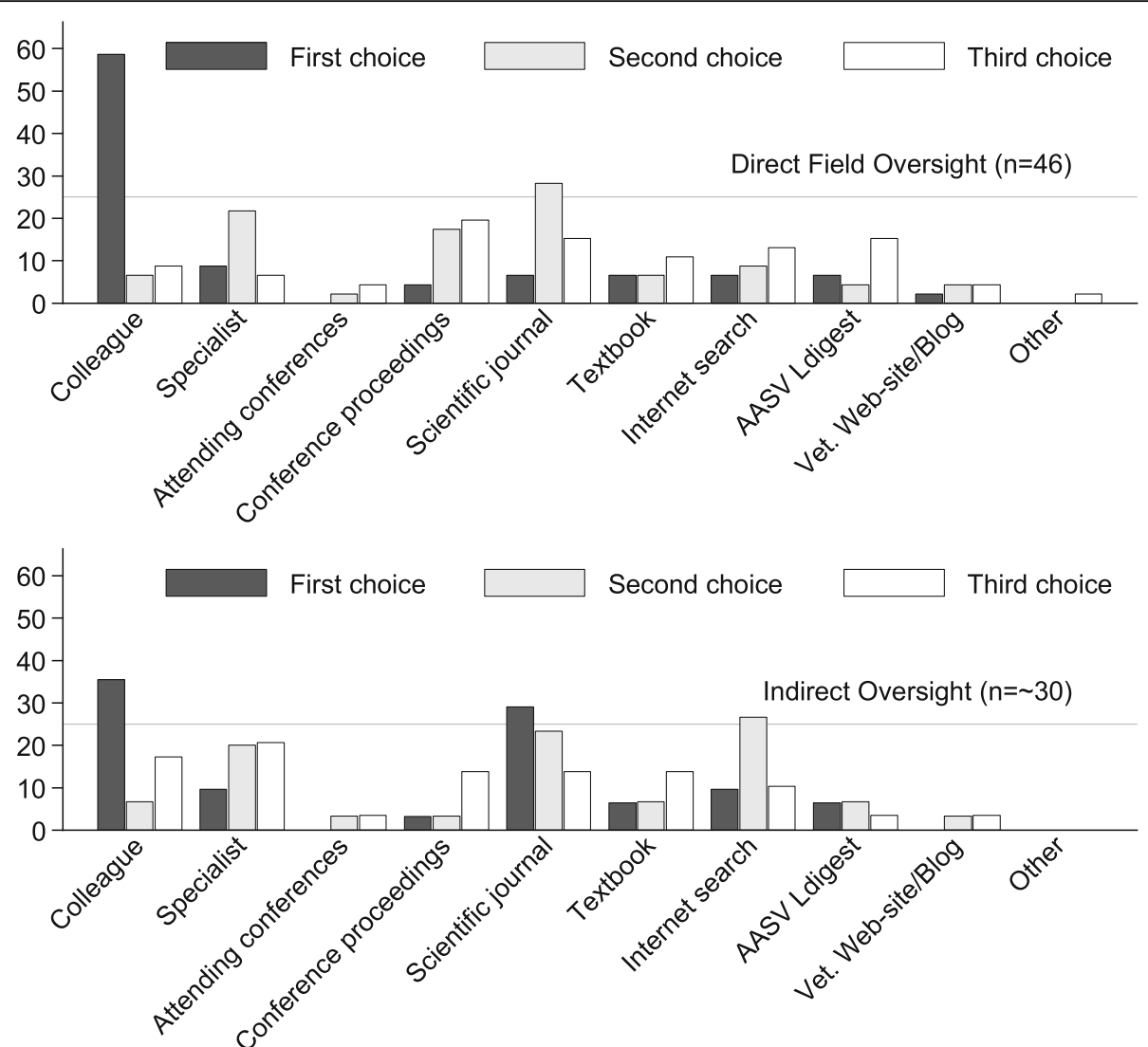

Fig. 2 (Q4) Frequency (\%) of rankings of first, second, and third choices for getting information for difficult clinical cases by role (direct vs indirect) (data supporting this figure are shown in Table 7 in Additional file 3)

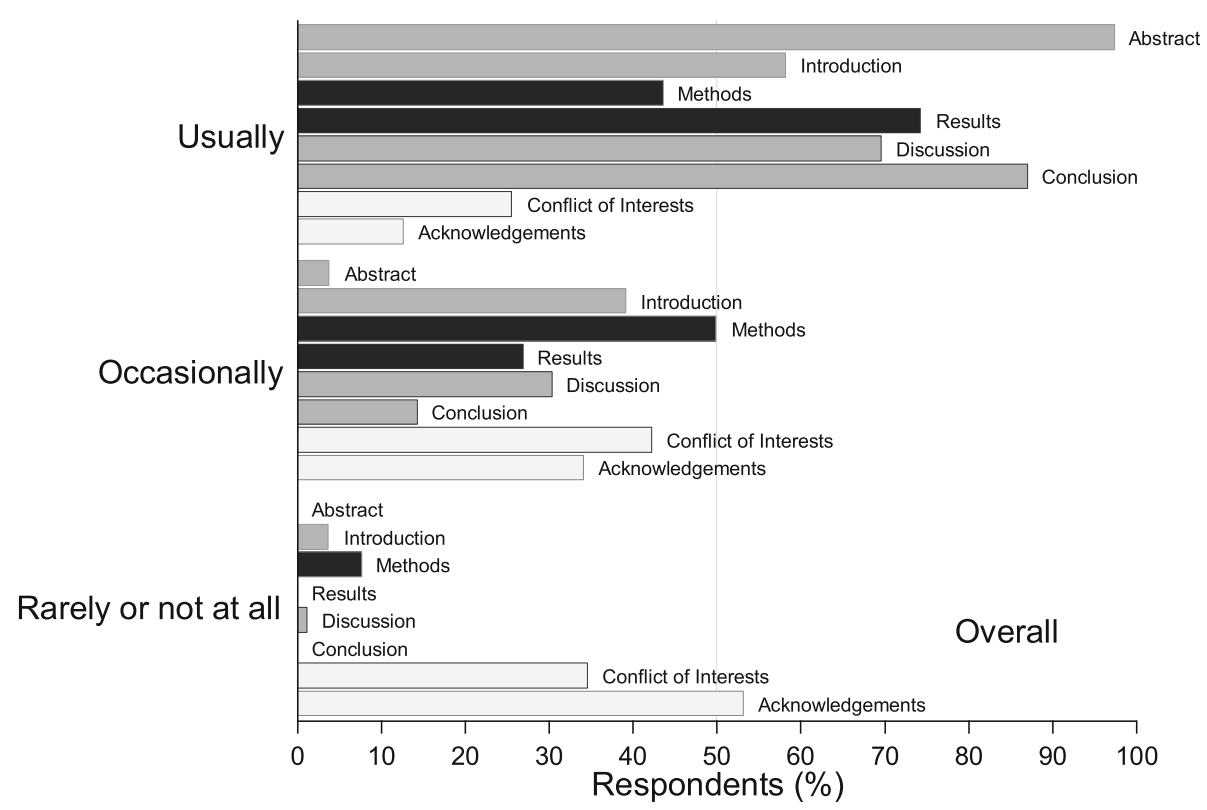

Fig. 3 (Q11) Overall reported frequency (\%) of reading of sections of journal articles $(n=79)$ (data supporting this figure are shown in Table 8 in Additional file 3) 
Table 4 Selection frequencies (\%) ${ }^{\mp}$ of most used search methods (up to two [2] options) (Q13) most used scientific journals for infectious disease information (up to three [3] options) (Q14), number of journals with subscription access (Q15), frequency of blocked full text access (Q16), awareness of article retrieval service (Q17), and conference attendance (Q24), by role

\begin{tabular}{|c|c|c|c|c|c|c|c|}
\hline & & \multicolumn{2}{|c|}{$\begin{array}{l}\text { Indirect } \\
\text { Oversight }{ }^{+}\end{array}$} & \multicolumn{2}{|c|}{$\begin{array}{l}\text { Direct } \\
\text { Oversight }{ }^{+\dagger}\end{array}$} & \multicolumn{2}{|c|}{ Overall } \\
\hline & & $\%$ & $95 \% \mathrm{Cl}$ & $\%$ & $95 \% \mathrm{Cl}$ & $\%$ & $95 \% \mathrm{Cl}$ \\
\hline \multicolumn{8}{|c|}{ Q13-Used most frequently to search for swine infectious disease research (up to 2 selections made). } \\
\hline Google or Google Scholar & Yes $(n=41)$ & 63 & {$[45,78]$} & 45 & {$[31,59]$} & 52 & {$[41,63]$} \\
\hline Bibliographic databases & Yes $(n=40)$ & 63 & {$[45,78]$} & 43 & {$[29,57]$} & 51 & {$[40,62]$} \\
\hline AASV Swine Information Library & Yes $(n=48)$ & 41 & {$[25,58]$} & 74 & {$[60,85]$} & 61 & {$[49,71]$} \\
\hline References in published studies & Yes $(n=12)$ & 16 & {$[7,33]$} & 15 & {$[7,28]$} & 15 & {$[9,25]$} \\
\hline Colleague recommended references & Yes $(n=11)$ & 9 & {$[3,26]$} & 17 & {$[9,31]$} & 14 & {$[8,24]$} \\
\hline Other & Yes $(n=3)$ & 3 & {$[0,20]$} & 4 & {$[1,16]$} & 4 & {$[1,11]$} \\
\hline \multicolumn{8}{|c|}{ Q14-Scientific journals used most for swine infection disease research (up to 3 selections made). } \\
\hline JSHAP & Yes $(n=70)$ & 78 & {$[60,89]$} & 96 & {$[84,99]$} & 89 & {$[79,94]$} \\
\hline Porcine Health Management & Yes $(n=4)$ & 9 & {$[3,26]$} & 2 & {$[0,14]$} & 5 & {$[2,13]$} \\
\hline JAVMA & Yes $(n=14)$ & 13 & {$[5,29]$} & 21 & {$[12,36]$} & 18 & {$[11,28]$} \\
\hline Preventive Veterinary Medicine & Yes $(n=11)$ & 28 & {$[15,46]$} & 4 & {$[1,16]$} & 14 & {$[8,24]$} \\
\hline The Veterinary Record & Yes $(n=6)$ & 6 & {$[2,22]$} & 9 & {$[3,21]$} & 8 & {$[3,16]$} \\
\hline Veterinary Clinics of North America & Yes $(n=1)$ & 3 & {$[0,20]$} & 0 & & 1 & {$[0,9]$} \\
\hline Journal of Animal Science & Yes $(n=13)$ & 6 & {$[2,22]$} & 23 & {$[13,38]$} & 16 & {$[10,27]$} \\
\hline Livestock Science & Yes $(n=3)$ & 3 & {$[0,20]$} & 4 & {$[1,16]$} & 4 & {$[1,11]$} \\
\hline JVDI & Yes $(n=13)$ & 28 & {$[15,46]$} & 9 & {$[3,21]$} & 16 & {$[10,27]$} \\
\hline Veterinary Research & Yes $(n=12)$ & 22 & {$[11,40]$} & 11 & {$[4,23]$} & 15 & {$[9,25]$} \\
\hline Canadian Veterinary Journal & Yes $(n=24)$ & 31 & {$[17,49]$} & 30 & {$[18,45]$} & 30 & {$[21,42]$} \\
\hline Other & Yes $(n=8)$ & 9 & {$[3,26]$} & 11 & {$[4,23]$} & 10 & {$[5,19]$} \\
\hline \multicolumn{8}{|c|}{ Q15-Number of scientific journals fully accessible through subscriptions. } \\
\hline 0 & $(n=3)$ & 6 & {$[2,22]$} & 2 & {$[0,14]$} & 4 & {$[1,11]$} \\
\hline $1-2$ & $(n=28)$ & 6 & {$[2,22]$} & 55 & {$[41,69]$} & 35 & {$[26,47]$} \\
\hline $3-4$ & $(n=12)$ & 9 & {$[3,26]$} & 19 & {$[10,33]$} & 15 & {$[9,25]$} \\
\hline $4-5$ & $(n=4)$ & 3 & {$[0,20]$} & 6 & {$[2,18]$} & 5 & {$[2,13]$} \\
\hline$>6$ & $(n=32)$ & 75 & {$[57,87]$} & 17 & {$[9,31]$} & 41 & {$[30,52]$} \\
\hline \multicolumn{8}{|c|}{ Q16-Frequency for which access to full research papers is blocked due to lacking subscriptions. } \\
\hline Often & $(n=18)$ & 13 & {$[5,29]$} & 30 & {$[18,45]$} & 23 & {$[15,34]$} \\
\hline Occasionally & $(n=26)$ & 31 & {$[17,49]$} & 34 & {$[22,49]$} & 33 & {$[23,44]$} \\
\hline Rarely & $(n=29)$ & 44 & {$[28,61]$} & 32 & {$[20,47]$} & 37 & {$[27,48]$} \\
\hline Not at all $(n=6)$ & $(n=6)$ & 13 & {$[5,29]$} & 4 & {$[1,16]$} & 8 & {$[3,16]$} \\
\hline \multicolumn{8}{|c|}{ Q17-Awareness of AASV journal retrieval service - Get it For Me } \\
\hline Yes & $(n=40)$ & 41 & {$[25,58]$} & 57 & {$[43,71]$} & 51 & {$[40,62]$} \\
\hline \multicolumn{8}{|c|}{ Q24-Attendance in the last two years of a conference presenting swine infectious disease research. } \\
\hline Yes & $(n=73)$ & 91 & {$[74,97]$} & 94 & {$[82,98]$} & 92 & {$[84,97]$} \\
\hline & Total $(n=79$ & & & & & & \\
\hline
\end{tabular}

† Indirect oversight $=$ non-practitioner that provides 1000 sows worth or less with direct veterinary services

†† Direct oversight $=$ practitioner or a non-practitioner that provides $>1000$ sows worth with direct veterinary services. $\mp$ Cells are color conditioned on blue to white with higher percentages as darkest blue

JSHAP = Journal of Swine Health and Production, JAVMA = Journal of the American Veterinary Medical Association, JVDI = Journal of Veterinary Diagnostic Investigation 
access to 1-2 journals (Table 4). Direct veterinarians were almost 9 times more likely to report access to $1-2$ journals versus indirect veterinarians $(\mathrm{PR}=8.9,95 \% \mathrm{CI}$ : 2.3-34.7, $p<0.01$ ), and, indirect veterinarians were over 4 times more likely to report access to $>6$ journals $(\mathrm{PR}=$ 4.4, 95\%CI: $2.3-8.5, p<0.01$.

Overall, 37\% (95\%CI: 27-48) of respondents reported online full journal article access was rarely blocked, 33\% (95\%CI: 23-44) as occasionally blocked, and $23 \%$ (95\%CI: 15-34) as often blocked (Table 4). There were no significant differences by role in reported blocked access. Of respondents reporting access to 1-2 journals only, almost half (48\%, 95\%CI: 30-67) reported occasionally being blocked, and 39\% (95\% CI: 19-63) as often blocked (see Table 9 in Additional file 3). Over half of respondents reporting rarely being blocked, also reported access to $>6$ journal subscriptions $(\mathrm{PR}=55$, 95\% CI: 37-72), but interestingly almost a third (31\%, 95\% CI: $17-50)$ of those reporting rarely being blocked also reported having access to 1-2 journals only (see Table 9 in Additional file 3). Overall, half (51\%, 95\%CI: 40-62) of respondents were aware of the Get-It-For-Me free membership service (Table 4) including 61\% (95\%CI: 37-81) of those also reporting online journal article access as often blocked (see Table 9 in Additional file 3 ). In the last two years, almost all respondents had attended a conference where swine infectious disease research information was presented (Table 4).

\section{Preferred reading material format}

Respondents were asked to select from a list of 6 options their two [2] preferred formats for reading materials for keeping current on infectious disease topics
(Table 5). Original individual primary research papers (IPRP) and one-page expert critical summaries of an IPRP were the most frequently selected options (both selected at 47\%, 95\%CI: 36-58) and full narrative expert critical review of the body of evidence (BOE) was least selected (15\%, 95\%CI:9-25). Preferences were not significantly different by role (see Table 10 in Additional file 3).

We compared respondents' preference for the full IPRP against their responses to questions on aspects of time, skill, and access (Fig. 4). Of respondents selecting a full IPRP as a preferred option, 43\% (95\%CI: 28-60) also reported not being able to explain the term confounding bias, approximately half (49\%, 95\%CI: 33-65) did not usually read the materials \& methods section of articles, and 14\% (95\%CI: 6-29) reported they have no confidence to assess, or that they do not assess, the appropriateness of the statistical methods used in an IPRP. Respondents who did not select full IPRPs were almost twice as likely to spend an hour or less per week keeping current $(\mathrm{PR}=1.8,95 \% \mathrm{CI}: 1.1-2.8, p=0.01)$ versus those who selected full IPRPs, and 3.5 times more likely to also report they have no confidence or do not evaluate the statistical methods used in a research study $(95 \% \mathrm{CI}$ : $1.5-8.5, p<0.01$ ) (see Table 11B in Additional file 3).

The most frequently selected combination of options included both a format involving an expert summary of the body of evidence (BOE) and a format involving content from an individual primary research paper (IPRP) (42\%, 95\%CI: 31-53) (Table 6). Over a third of respondents (34\%, 95\%CI: 24-46) selected exclusively options involving IPRPs. There were no significant differences in

Table 5 (Q18) Selection (\%) ${ }^{\mp}$ of preferred reading material formats for keeping current with infectious disease research (given a choice of up to two [2] options), by role

\begin{tabular}{|c|c|c|c|c|c|c|}
\hline \multirow[b]{2}{*}{ Scope/format of reading material } & \multicolumn{2}{|c|}{$\begin{array}{l}\text { Indirect } \\
\text { Oversight }\end{array}$} & \multicolumn{2}{|c|}{$\begin{array}{l}\text { Direct } \\
\text { Oversighttt }\end{array}$} & \multicolumn{2}{|c|}{ Overall } \\
\hline & $\%$ & $95 \% \mathrm{Cl}$ & $\%$ & $95 \% \mathrm{Cl}$ & $\%$ & $95 \% \mathrm{Cl}$ \\
\hline \multicolumn{7}{|l|}{ Body of Evidence } \\
\hline Full narrative expert critical review report $(n=12)$ & 16 & {$[7,33]$} & 15 & {$[7,28]$} & 15 & {$[9,25]$} \\
\hline Three (3) page summary of an expert critical review $(n=19)$ & 25 & {$[13,43]$} & 23 & {$[13,38]$} & 24 & {$[16,35]$} \\
\hline One (1) page summary of an expert critical review $(n=24)$ & 25 & {$[13,43]$} & 34 & {$[22,49]$} & 30 & {$[21,42]$} \\
\hline \multicolumn{7}{|l|}{ Individual primary research paper } \\
\hline Full research paper $(n=37)$ & 50 & {$[33,67]$} & 45 & {$[31,59]$} & 47 & {$[36,58]$} \\
\hline One (1) page expert critical summary $(n=37)$ & 38 & {$[22,55]$} & 53 & {$[39,67]$} & 47 & {$[36,58]$} \\
\hline Other $(n=4)$ & 9 & {$[3,26]$} & 2 & {$[0,14]$} & 5 & {$[2,13]$} \\
\hline
\end{tabular}

† Indirect oversight $=$ non-practitioner that provides 1000 sows worth or less with direct veterinary services

t† Direct oversight $=$ practitioner or a non-practitioner that provides $>1000$ sows worth with direct veterinary services

$\mp$ Cells are color conditioned on blue to white with higher percentages as darkest blue

*Total does not add to 79 as respondents chose up to 2 options, ${ }^{* *}$ Other options reported included podcasts to listen to while driving, abstracts from papers, a

summary report of the evidence, and a systematic review 
Time Q7- $1 \mathrm{hr}$ or less per week

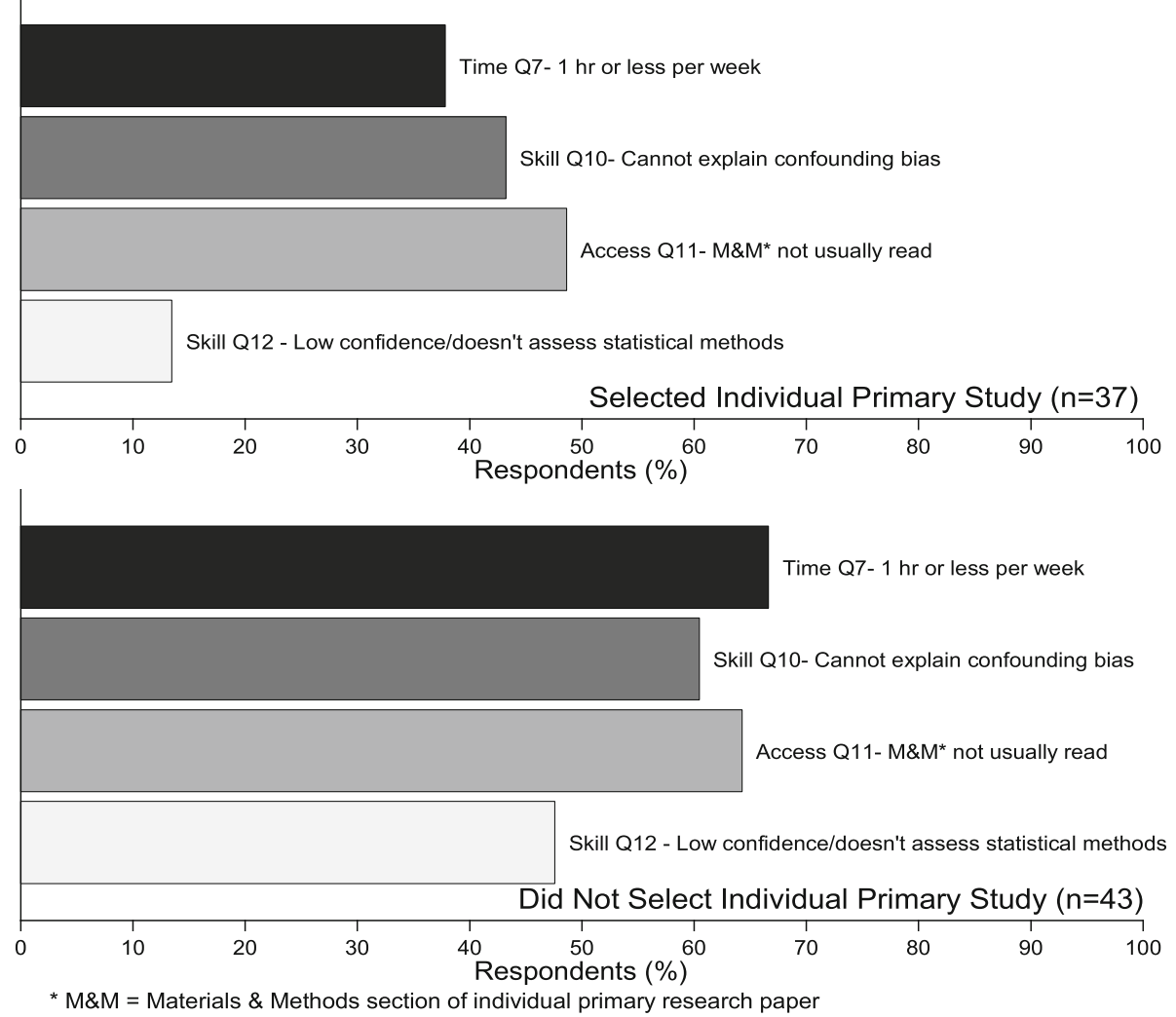

Fig. 4 (Q18) Comparison of frequencies (\%) of respondents reporting all of four defining KT barriers between those who selected for keeping current full text individual primary research papers (IPRP) versus those who did not. Defining KT barriers include 1) an hour or less available per week to keeping up, 2) low confidence to assess statistical methods used in a study, 3) inability to explain confounding bias, and 4) does not usually read methods section) (data supporting this figure are shown in Table 11A in Additional file 3)

the selection of combinations by veterinarian role (see Table 12 in Additional file 3). Respondents reporting 'moderate to high stress' were 4.3 times more likely to select exclusively BOE options versus respondents reporting 'little to no stress' ( $\mathrm{PR}=4.3,95 \% \mathrm{CI}$ : $1.0-17.9$, $p=0.02)$.

\section{Discussion}

Veterinary licensing bodies expect licenced veterinarians to keep aware of the significance, relevance and validity of current research [30]. Continuing education (CE) and continuing professional development (CPD) are often mandatory obligations for licensure and are, for the most

Table $6(\mathrm{Q} 18)$ Frequency $(\%)^{\mp}$ of selected two-option combinations of preferred content type (BOE or IPRP) for reading materialsł used to keep current with research on a specific disease topic, by role

\begin{tabular}{|c|c|c|c|c|c|c|}
\hline & \multicolumn{2}{|c|}{$\begin{array}{l}\text { Indirect } \\
\text { Oversight } \uparrow\end{array}$} & \multicolumn{2}{|c|}{$\begin{array}{l}\text { Direct } \\
\text { Oversight }+\dagger\end{array}$} & \multicolumn{2}{|c|}{ Overall } \\
\hline & $\%$ & $95 \% \mathrm{CI}$ & $\%$ & $95 \% \mathrm{CI}$ & $\%$ & $95 \% \mathrm{CI}$ \\
\hline Both a BOE and an IPRP format selected $(n=33)$ & 41 & {$[25,58]$} & 43 & {$[29,57]$} & 42 & {$[31,53]$} \\
\hline Only IPRP format single choice or as both options $(\mathrm{n}=27)$ & 31 & {$[17,49]$} & 36 & {$[24,51]$} & 34 & {$[24,46]$} \\
\hline Only BOE format single choice or as both options $(n=15)$ & 19 & {$[9,36]$} & 19 & {$[10,33]$} & 19 & {$[12,29]$} \\
\hline $\begin{array}{l}\text { Other single choice or in combination with other formats } \\
(\mathrm{n}=4)\end{array}$ & 9 & {$[3,26]$} & 2 & {$[0,14]$} & 5 & {$[2,13]$} \\
\hline
\end{tabular}

Total $(\mathbf{n}=79) *$

F Cells are color conditioned on blue to white with higher percentages as darkest blue

$\mathrm{BOE}=$ content summarizing body of evidence, IPRP = content derived from a single individual primary research paper

₹ reading material formats could be either a full report, a 3 page summary, or 1 page summary

† Indirect oversight $=$ non-practitioner that provides 1000 sows worth or less with direct veterinary services

t† Direct oversight $=$ practitioner or a non-practitioner that provides $>1000$ sows worth with direct veterinary services

*Total does not add to 79 - respondents chose up to 2 options 
part, self-directed by veterinarians [30]. Cumulative increases in research technical rigor suggests however, that staying current is an increasingly onerous individual burden [31-35].

\section{Time}

Time is the most consistently reported KT barrier across all previous veterinarian surveys and a consistently reported obstacle to participation in CE/CPD [10, 12, 16, 36-43]. Understandably then, time constrained swine veterinarians seek colleagues, may select citations by convenience [12, 44], or seek narrative reviews for keeping up; with the latter two being at odds with the practice of EBM [45-49]. Synthesis has been described as the basic unit of knowledge translation KT [11] and within an EBM framework research synthesis involves robust and consistent steps to mitigate risk of bias when assimilating knowledge [50]. The impact of how veterinarians allocate time on their effectiveness with keeping up will be important to evaluate further. For example, over 275 primary research publications were identified as relevant following a recent search for primary literature on IAV-S vaccines in swine [51]. It may not be a pragmatic choice for many of the respondents in this survey to try to access and to assess this body of evidence simply given the reported time they allot each week to staying current.

\section{Process efficiency and stress}

Veterinary professional stress has been reported elsewhere [52]. The substantial proportion of swine veterinarians reporting high levels of stress and limited efficiency with the process of keeping up is concerning. Veterinary student confidence to appraise research has been associated with KT process efficiency [36]. This was a similar finding of this study and we believe this is the first survey of working agri-food public health veterinarians associating individual efficiency and stress with the process of keeping current. The relationship between $\mathrm{KT}$ barriers and stress in veterinarians is worth further investigation.

\section{Access}

Swine veterinarian preference to consult with colleagues first for additional information is consistent with findings of other surveys $[12,17,43,53,54]$, but swine veterinarians may differ in having greater preference to refer to journals. The distribution of relevant publications across journals complicates efforts to practice EBM for veterinarians with limited access to journal subscriptions. For example, over the last 30 years, IAV-S vaccine primary research has been published across 51 different journals, most of which are not open access or those preferred by respondents in this survey [51].

\section{Skill}

Both topic and study design expertise is needed to assess validity [55-59]. Vaccine program management is a population medicine touchstone and understanding of the terms in this survey was assumed as fundamental [60-62]. Respondent overall low familiarity with $R_{0}$ and Risk Ratio is worth further investigation, particularly if such short-comings translate into inappropriate extrapolations from vaccine efficacy or effectiveness studies to disparate field conditions. Understanding of types and causes of bias underpins skill to assess studies [63, 64]. Reported low familiarity with bias is consistent with finding of Vandeweerd et al. [12]. Lacking of familiarity with the term evidence pyramid was incongruent with high reported understanding of EBM. We did not explore however if this also equates with a low understanding of the hierarchical relationship of study design with susceptibility to bias.

\section{Critical appraisal versus information management}

Consistent with previous surveys [36, 53, 65], the majority of respondents do not usually read methods sections of articles. By default then, it is reasonable to conclude that the majority also do not usually assess study validity, possibly also increasing the likelihood of assimilating biased information into practice. Although not a finding of this survey, student avoidance of methods sections was attributed to low confidence in critical appraisal skills [36].

Logically, recommendations for both human health and veterinary practitioners are to improve skills to critically appraise primary studies through training in the traditional skills of EBM; question formulation, comprehensive searching, determining relevance, critical assessment, synthesis, and presentation of findings [66-71]. While veterinarians report interest in such training [65, 72] emphasis on this approach might not be optimal for the profession. Training and maintenance of traditional EBM skills, through CE/CPD for example, while necessary and important, requires an investment of time, and considerable numerical literacy [16, 36, 73-76]. Opinions also differ on how to teach EBM/EBVM, and best methods for teaching are not clear [76]. Shurtz et al. [10] surveyed 22 U.S. and Canadian veterinary colleges and found no consistency in approaches to teaching EBVM skills within schools or between schools. Time, competing curriculum, perceived limited importance of EBVM, and the difficulty of teaching critical assessment, were the chief challenges to teaching EBVM skills $[10,36]$.

Alternatively, others recommend instead greater emphasis on teaching skills for information management over teaching traditional EBM skills [33, 34]. The rationale is that skill to quickly identify sources of relevant, synthesized, and contextualized information is highly 
advantageous in time constrained environments and more conducive to rapid end-user uptake of the best available research $[5,33,34]$. Importantly, however, the caveat is that robust and applicable syntheses are also readily accessible [5, 11, 34, 77].

\section{Syntheses versus primary research}

It is noteworthy, considering reported challenges with time, skill, and access, that a significant proportion of respondents preferred individual primary research studies for staying current over expert summaries of the body of evidence. The reason for this preference is unknown. Low awareness of the advantages of using research syntheses, low awareness of available syntheses [10, 36, 78], few available syntheses, or difficulty accessing appropriate contextual or plain language summaries [79-81] may explain this finding. Alternatively, IPRPs may be sought based on authorship, to find research in support of clinical recommendations, or to review the methods reported in consideration of a future research study design; each of which may be problematic if there is collectively low professional awareness of issues with reliance on informal methods for selection of primary research [8, 82-87].

\section{Limitations}

Participant self-selection and self-reporting may have biased results to reflect greater KT barriers. Experienced veterinarians may be over-represented; we did not explore association of years of practice with reported levels of skill, time or access. A $6 \%(80 / 1289)$ response rate is low and may not be representative of the source population. However demographics matched the AASV's membership and conservative estimates suggest survey participants represented responses from veterinarians directly influencing a minimum of 2 million commercial pigs or $26 \%$ of the Canadian national sow herd [88], and approximately $9 \%$ of the US national sow herd [89]. Post survey, the epidemiological situation for African Swine Fever virus in Asia, and the diagnostic investigations related to Senecavirus A have changed possibly affecting updated rankings for these pathogens.

Disproportionate responses from Canadian versus overall member responses ( $29 \%$ vs $6 \%)$ suggests advocacy may improve response; the CASV president encouraged participation at the CASV annual meeting, sending also three single purpose emailed reminders, as did Canadian regional swine association presidents both formally (group email) and informally. Lastly, the AASV Get-it For-Me service has since been discontinued.

\section{Conclusions}

Swine veterinarians seek information predominantly on topics of endemic infectious diseases over other aspects of veterinary medicine, and colleagues, specialists and journals are important sources of information. The process of keeping up is stressful and not optimally efficient for many swine veterinarians. KT barriers are substantial and do not differ in large part from those for other veterinarians as reported in previous literature. This suggests a need to improve KT infrastructure. The current professional paradigm has veterinarians customizing their own path for keeping current using skills such as searching for, identifying, and appraising primary research. Findings also illustrate a need for additional training on epidemiologic principles, statistical methods, and interpretation of primary research, however notable potential shortcomings with emphasis on this strategy for $\mathrm{CE} / \mathrm{CPD}$ were also discussed. Reasons why veterinarians choose to review primary research over syntheses is worth further evaluation. Consideration of this will be important in the planning of $\mathrm{KT}$ infrastructure improvements.

\section{Methods \\ Survey timeline}

The survey was launched online through the American Association of Swine Veterinarians (AASV) weekly eletter to its membership on March 16, 2016, and closed April 26th, 2016.

\section{Survey development}

The survey was generated using Qualtrics Survey Software, Copyright $\odot 2016$ Qualtrics, Provo, UT, USA. http://www.qualtrics.com available on license through the University of Guelph, Canada. Submissions were anonymous and no personal data were collected. Participation was incentivized with voluntary entry to a draw for a copy of Disease of Swine 10th edition (identities protected). The survey was offered in three languages (English, French and Spanish) and structured for online completion in 10 min or less via PC or mobile devices. The online survey tool was pre-tested in February 2016 by 10 experts geographically from Canada, the USA and the UK, in practitioner, academic, and government veterinary roles, and with expertise in swine veterinary medicine, and evidence based methodology.

\section{Question development}

Full text for the survey tool is available in Additional file 2. Questions were grouped into three blocks; Block 1 identified interests, motivations, and priority information sources, Block 2 explored KT barriers of time, access, skill, and process, and format preferences for written information, Block 3 captured information on demographics and conference attendance. A differentiating question $(\mathrm{Q} 23)$ in the Block 3 asked respondents to quantify their direct field oversight of swine production in terms of "sows worth of 
production", which reflects influence over quantities of offspring entering the market. For all analyses of measures of association by veterinary role, respondents self-identifying as practitioners or reporting oversight of greater than 1000 sows worth of production were assigned the designated role of "direct oversight", and respondents self-identifying as nonpractitioners and reporting oversight of 1000 or fewer sows worth of production were assigned "indirect oversight" as their role.

All questions formatted as lists of options included also the option of 'other' and provision of open ended text boxes for elaboration. Likert scales $(3,4$, and 5 point) were used for questions on opinions. Two questions addressed skill; self-report of familiarity with knowledge terms, and confidence level to appraise three aspects of research conduct (study design, choice of statistical analysis, and interpretation of findings). Knowledge terms were selected where understanding was believed pre-requisite to engagement in research appraisal. Terms were also selected as groupings with strong construct validity where understanding of one term implied that there would be understanding of the other terms in the group [64, 68]. Respondents were given a list of six options to explore preferred reading material length and format for keeping current with research; original primary research study, third party review of the individual study, or third party review of the body of evidence.

\section{Survey administration}

The target population, the source population, and the sampling frame, respectively, were swine practitioners globally, the 2016 American Association of Swine Veterinarians (AASV) membership, and the AASV members subscribing to the AASV weekly e-letter. AASV members (1289) are involved in practice, industry and academia, in more than 40 countries [90]. Researchers sought prior approval and generated awareness for the survey with both the AASV and the Canadian Association of Swine Veterinarians (CASV) boards in early planning stages. A priori, no formal sample size calculation was performed understanding a $10 \%$ response rate was expected based on previous efforts to survey the membership, and that almost $100 \%$ of the membership received the e-Letter (AASV Associate Director, personal communication). Additional marketing included printed material displayed at the 47th AASV annual meeting registration table, and CASV president endorsement at the CASV annual board meeting. The survey link was posted in the e-Letter followed by three reminder notices at two week intervals, and remained accessible online for the duration of the survey period.

\section{Data entry and manipulation}

Online submissions were collected using Qualtrics software and downloaded for analysis to Stata, StataCorp. 2015. Stata Statistical Software: Release 14. College Station, TX: StataCorp LP. Responses were excluded if respondents did not identify their role or self- identified as non-veterinarians.

\section{Statistical analysis}

Proportions of responses were calculated both overall and stratified by designated veterinary role (as direct versus indirect). For the purposes of inferential analysis, categorical response options with more than two categories were aggregated into dichotomous outcomes (see Table 2 in Additional file 3). This was a post hoc decision due to the low survey response. Contingency tables were then used to estimate proportions by veterinary role and to generate prevalence ratios (PR) (and 95\% confidence intervals). Fisher's exact test was used to determine statistical significance of associations. Cronbach's alpha was used to assess the internal consistency of responses to questions on self-reported level of skills to assess research [91, 92], with values ranging from 0.70 to 0.95 interpreted as acceptable [91].

\section{Supplementary information}

Supplementary information accompanies this paper at https://doi.org/10. 1186/s12917-020-02617-8.

Additional file 1: Figure 1. Timeline of Milestones for Veterinary Knowledge Translation Surveys, Evidence Based Medicine (EBM), and online (digital) information access. Table 1. Veterinary published surveys inclusive of a focus on KT barriers, veterinary information needs, or continuing education.

Additional file 2. Full copy of English version original Survey text of the Swine Veterinarian Infectious Disease Research Access Survey as launched March 2016 through the AASV e-Letter.

Additional file 3: Table 1. Demographics (\%) of survey respondent by self-identified veterinary role. Figure 1. Demographic composition by role (\%) of survey respondents versus the AASV membership. Table $\mathbf{2 A}$. Summary of post hoc grouping of the multiple response options for each survey question into dichotomous responses for analysis (used in calculation of all prevalence ratios). Table $\mathbf{2 B}$. Self-reported veterinary role as practitioner or non-practitioner versus dichotomized role. Table $\mathbf{2 C}$. Selfreported veterinary role versus sows worth of veterinary oversight. Table 2D. Dichotomized veterinary role versus sows worth of veterinary oversight. Table 3. Dichotomised responses* for reported level of process efficiency (Q8) and level of process stress with staying current (Q9) versus role (direct vs. indirect). Table 4. (Q10) Self-reported familiarity with epidemiologic and evidence based terminology, by role. Response options not dichotomized (i.e the same information but dichotomized responses only are shown in Table 3 of main body of manuscript). Table 5. (Q12) Self -reported level of confidence to assess aspects of a research paper, by role (direct vs. indirect). Table 6A. (Q12) Self -reported level of confidence to assess aspects of a research paper, by role (direct vs. indirect) with responses dichotomized* as 'Confident' or 'No Confidence/Do not evaluate'. Table 6B. (Q12) Association of having confidence* with usually reading* versus not usually reading the methods section of journal articles. Table 7. (Q4) Ranking of first (1st), second (2nd), and third (3rd) choices for getting more information for difficult clinical cases, by role 
(direct vs. indirect). Table 8. (Q11) Self-reported frequency of reading sections of scientific journal articles, by role. Table $\mathbf{9}$. Self-reported scientific journal access (Q15) and article service awareness (Q17) by frequency of blocked access (Q16) (Often, Occasionally, Rarely, Not at all). Table 10. (Q18) Association of selection of a preferred reading material format (for keeping current with a specific infectious disease topic) with veterinary role. Table 11A. (Q18) Respondent self-reported time ${ }^{*}(Q 7)$, skill*(Q10,12) and access ${ }^{*}(\mathrm{Q} 11)$ by their choice of individual primary research papers (IPRP) as a preferred reading format for keeping current with a specific disease topic (IPRP not selected vs IPRP selected). Table 11B. (Q18) Association of time, skill and access for respondents with not selecting IPRP* versus selecting IPRP as a preferred reading format. Table 12. (Q18) Association of selected combinations of choices* of reading material format options with direct ${ }^{\dagger}$ veterinary role versus indirect ${ }^{\dagger+}$ veterinary role.

\section{Abbreviations}

AASV: American Association of Swine Veterinarians; BOE: Body of evidence; CASV: Canadian Association of Swine Veterinarians; CE/CPD: Continuing education/continuing professional development; EAPHM: European Association for Porcine Health Management; EBM: Evidence Based Medicine; EBVM: Evidence Based Veterinary Medicine; IAV: Influenza A virus; IPRP: Individual primary research paper; JSHAP: Journal of Swine Health and Production; KT: Knowledge translation; PEDv: Porcine Epidemic Disease virus; PR: Prevalence ratio; PRRS: Porcine Reproductive and Respiratory Syndrome

\section{Acknowledgements}

We acknowledge and are thankful for the advice and support for this survey from Dr. George Charbonneau, Dr. Sue Schulteis, Dr. Mike DeGroot, Dr. Marnie Brennen, Ms. Karen Richardson and our colleagues who agreed to pre-test the survey. We also are grateful to Dr. Maria Rocio Amezcua and Emilie Belage for survey translation services.

\section{Dedication}

We dedicate this work to Dr. Bob Morrison, whose tragic loss is felt deeply by swine veterinarians. His leadership and commitment to working together helped shape the optimistic spirit of this unique community.

\section{Authors' contributions}

Conceptualization, methodology (SK, ZP, JMS, AO, RF, TO), funding acquisition, project administration, investigation(SK, ZP), formal analysis $(\mathrm{SK}, \mathrm{ZP}, \mathrm{JMS}, \mathrm{AO})$, data curation, visualization and writing original draft (SK, ZP), manuscript review and editing (SK, ZP, JMS, AO, RF, TO). The authors read and approved the final manuscript.

\section{Author information}

Cumulatively, authors' AASV membership extends multiple decades. ZP is a member of the editorial board of PVM, RF is associate editor of CVJ, and TO is the JSHAP executive editor. JMS is a member of the editorial board of $\mathrm{ZPH}$, and section editor for AHRR. AOC is an associate editor for JVIM and section editor for AHRR

\section{Funding}

This survey was funded by an Ontario Veterinary College Fellowship grant and The Ontario Ministry of Food Agriculture and Rural Affairs (OMAFRA) project\# KTT2015-10253. Funders had no other role in this work other than requiring compliance with ethical standards.

\section{Availability of data and materials}

The datasets generated and/or analysed during the current study are not publicly available due to terms of the participant consent agreement, but are available from the corresponding author on reasonable request.

\section{Ethics approval and consent to participate}

Survey conduct, and data were handled and stored, as approved by the University of Guelph's Research Ethics Board for compliance with Canadian federal guidelines for research involving human participants (REB\# 16JA029). Participant selection of the option 'l agree to participate' on the first page of the online survey tool was considered explicit consent. Participants were then allowed access to the survey questions.

\section{Consent for publication}

Informed consent for publication of survey responses was obtained from participants as noted above. Please see Additional file 2 for a copy of the consent form (on the first page, preceding the survey questionnaire).

\section{Competing interests}

The authors declare that they have no competing interests.

\section{Author details}

${ }^{1}$ Department of Population Medicine, Ontario Veterinary College, University of Guelph, Guelph, Canada. ${ }^{2}$ Centre for Public Health and Zoonoses, Ontario Veterinary College, University of Guelph, Guelph, Canada. ${ }^{3}$ Department of Large Animal Clincal Sciences, College of Veterinary Medicine, Michigan State University, East Lansing, Michigan, USA.

\section{Received: 8 November 2019 Accepted: 9 October 2020 \\ Published online: 02 November 2020}

\section{References}

1. Sackett DL, Rosenberg WMC, Gray JAM, Haynes RB, Richardson WS. Evidence based medicine : what it is and what it Isn ' t. Br Med J. 1996; 312(7023):71-2..

2. Estabrooks CA, Derksen L, Winther C, Lavis JN, Scott SD, Wallin L, et al. The intellectual structure and substance of the knowledge utilization field: a longitudinal author co-citation analysis, 1945 to 2004. Implement Sci. 2008; 3(1):1-22.

3. Kothari A, Rudman D, Dobbins M, Rouse M, Sibbald S, Edwards N. The use of tacit and explicit knowledge in public health: a qualitative study. Implement Sci. 2012;7(1):20 Available from: http://www. implementationscience.com/content/7/1/20.

4. Polanyi M. The tacit dimension. Garden City,New York: Doubleday \& Company, Inc.; 1966.

5. Straus S, Haynes RB. Managing evidence-based knowledge: the need for reliable, relevant and readable resources. Cmaj. 2009;180(9):942-5.

6. Yih-Tong Sun P, Scott JL. An investigation of barriers to knowledge transfer. J Knowl Manag. 2005;9(2):75-90 Available from: http://www.emeraldinsight. com/doi/10.1108/13673270510590236.

7. Graham ID, Logan J, Harrison MB, Straus SE, Tetroe J, Caswell W, et al. Lost in knowledge translation: time for a map? J Contin Educ Heal Prof. 2006; 26(1):13-24.

8. Grimshaw J, Eccles M, Lavis J, Hill S, Squires J. Knowledge translation of research findings. Implement Sci. 2012;7(1):50. Available from: citeulikearticle-id:10736056\%5Cn. https://doi.org/10.1186/1748-5908-7-50.

9. Kajermo KN, Boström A-M, Thompson DS, Hutchinson AM, Estabrooks CA, Wallin L. The BARRIERS scale--the barriers to research utilization scale: A systematic review. Implement Sci. 2010;5(1):32 Available from: http://www. implementationscience.com/content/5/1/32.

10. Shurtz S, Fajt $V$, Heyns EP, Norton HF, Weingart S. Teaching evidence-based veterinary medicine in the US and Canada. J Vet Med Educ. 2017;44(4):6608.

11. Rajić A, Young I, McEwen SA. Improving the utilization of research knowledge in Agri-food public health: a mixed-method review of knowledge translation and transfer. Foodborne Pathog Dis. 2013;10(5):397412 Available from: http://online.liebertpub.com/doi/abs/10.1089/fpd.2 012.1349 .

12. Vandeweerd J-M, Vandeweerd S, Gustin C, Keesemaecker G, Cambier C, Clegg $P$, et al. Understanding veterinary practitioners' decision-making process: implications for veterinary medical education. J Vet Med Educ. 2012;39(2):142-51 Available from: http://jvme.utpjournals.press/doi/10.3138/ jvme.0911.098R1.

13. Vandeweerd JM, Kirschvink N, Clegg P, Vandenput S, Gustin P, Saegerman C. Is evidence-based medicine so evident in veterinary research and practice? History, obstacles and perspectives. Vet J. 2012;191(1):28-34. https://doi.org/10.1016/j.tvjl.2011.04.013.

14. Alders R, de Bruyn J, Wingett $K$, Wong J. One health, veterinarians and the nexus between disease and food security. Aust Vet J. 2017;95(12):451-3.

15. Sargeant JM, Rajic A, Read S, Ohlsson A. The process of systematic review and its application in Agri-food public-health. Prev Vet Med. 2006;75(3-4): 141-51.

16. Delver HA. Continuing veterinary medical education needs and delivery preferences of Alberta veterinarians. J Vet Med Educ. 2008;35(1):129-37. 
17. Meehan MP, Harburg KN. Information sources used by veterinarians and their perceptions of the ASAVA and the AVP. Aust Vet Pract. 2010;40(3):109-18.

18. Nielsen TD, Dean RS, Robinson NJ, Massey A, Brennan ML. Survey of the UK veterinary profession: common species and conditions nominated by veterinarians in practice. Vet Rec. 2014;174(13):324.

19. National Research Council. Critical Role of Animal Science Research in Food Security and Sustainability. Washington, DC: The National Academies Press; 2015. p. 416.

20. McDermott JJ, Schukken YH, Shoukri MM. Study design and analytic methods for data collected from clusters of animals. Prev Vet Med. 1994;18: 175-91. https://doi.org/10.1016/0167-5877(94)90074-4.

21. National Research Council. Animal Health at the Crossroads: Preventing, Detecting, and Diagnosing Animal Diseases [Internet]. Washington, DC: The National Academies Press; 2005. p. 286. Available from: https://www.nap. edu/catalog/11365/animal-health-at-the-crossroads-preventing-detectingand-diagnosing-animal.

22. $\mathrm{FAO}, \mathrm{OIE}, \mathrm{WHO}$. The FAO-OIE-WHO collaboration: Sharing responsibilities and coordinating global activities to address health risks at the animalhuman-ecosystems Interface. A Tripartite Concept Note. 2010. p. 1-8.

23. Harris DL. Breeding stock production, in multi-site pig production. Ames, lowa: lowa State University Press; 2000.

24. Perez AM, Davies PR, Goodall CK, Holtkamp DJ, Mondaca-Fernández E, Poljak Z, Tousignant SJ, et al. Lessons learned and knowledge gaps about the epidemiology and control of porcine reproductive and respiratory syndrome virus in North America. JAVMA. 2015;246(12):1304-17.

25. Neuman J, Persons TM. Report to the Chairman, Committee on Energy and Commerce, House of Representatives. Emerging animal diseases: Actions needed to better position USDA to address future risks. GAO-16-132. Washington, DC: United States Government Accountability Office; 2015.

26. Leboucq N, D'Alessio F, Bucher K. Required competencies of Veterinary Services in the context of international trade: opportunities and challenges [Internet]. OIE 2020 Technical Item. 2020 [cited 2020 Aug 25]. Available from: https://www.oie.int/en/conferences-events/2020-world-assembly-ofthe-oie-delegates/technical-item/.

27. Penny R, Penny J. Priorities for pig research: the results of the second pig veterinary society questionnaire. In: Proceedings - The Pig Veterinary Society; 1978. p. 119-24.

28. Maes D, vander Beken $H$, Dewulf J, de Vliegher S, Castryck F, de Kruif A. The functioning of the veterinarian in the Belgian pig sector: a questionnaire survey of pig practitioners. Vlaams Diergeneeskd Tijdschr. 2010;79(3):218-26

29. Marvin DM, Dewey CE, Rajić A, Poljak Z, Young B. Knowledge of zoonoses among those affiliated with the Ontario swine industry: a questionnaire administered to selected producers, allied personnel, and veterinarians. Foodborne Pathog Dis. 2010;7(2):159-66.

30. Caple I. Continuing professional developemnt for veterinarians - clinical review. Aust Vet J. 2005;83(4):200-2.

31. Centers for Disease Control and Prevention. History of Statistics in Public Health at CDC, 1960-2010: the Rise of Statistical Evidence. MMWR. 2011; 60(Suppl):35-41. Available from: https://www.cdc.gov/mmwr/pdf/other/su6 004.pdf. Accessed 21 Sept 2017.

32. Plaven-Sigray P, Matheson G, Schiffler BC, Thompson WH. Readability of scientific text decreases over time. Elife. 2017;6:1-14.

33. Slawson DC, Shaughnessy AF. Teaching evidence-based medicine : should instead? Acad Med. 2005;80(7):685-9.

34. Hurwitz SR, Slawson DC. Should we be teaching information management instead of evidence-based medicine? Clin Orthop Relat Res. 2010;468(10):2633-9.

35. Perez AM. Past, present, and future of veterinary epidemiology and economics: one health, many challenges, no silver bullets. Front Vet Sci. 2015;2(November):1-4 Available from: http://journal.frontiersin.org/Article/1 0.3389/fvets.2015.00060/abstract.

36. Eldermire ERB, Fricke S, Alpi KM, Davies E, Kepsel AC, Norton HF. Information seeking and evaluation: a multi-institutional survey of veterinary students. J Med Libr Assoc. 2019;107(4):515-26.

37. Moore DA, Klingborg DJ, Brenner JS, Gotz AA. Perspectives in professional education in continuing veterinary medical education. J Am Vet Med Assoc. 2000;217(7):1001-6.

38. Dale VHM, Pierce SE, May SA. The importance of cultivating a preference for complexity in veterinarians for effective lifelong learning. J Vet Med Educ. 2010;37(2):165-71 Available from: http://jvme.utpjournals.press/doi/10.3138/ jvme.37.2.165.
39. Dale VHM, Kinnison T, Short N, May SA, Baillie S. Web 2.0 and the veterinary profession: Current trends and future implications for Lifelong Learning. Vet Rec. 2011;169(18):467. https://doi.org/10.1136/vr.d4897. Epub 2011 Sep 2.

40. Dale VHM, Pierce SE, May SA. Motivating factors and perceived barriers to participating in continuing professional development: a national survey of veterinary surgeons. Vet Rec. 2013;173:247 Available from: http://www.ncbi. nlm.nih.gov/pubmed/23980235.

41. Chun M-S, Hwang C-Y. Continuing veterinary medical education needs assessment of small animal practitioners in South Korea. J Vet Med Educ. 2015;42(3):232-8.

42. Huntley S, Dean R, Brennan M. The Awareness of the International Veterinary Profession of Evidence-Based Veterinary Medicine and Preferred Methods of Training. Vet Sci. 2017;4(1):15 Available from: http://www.mdpi. com/2306-7381/4/1/15.

43. Haimerl $P$, Arlt $S$, Heuwieser W. Entscheidungsfindung in der tierartlichen Praxis. Tierarztl Prax Kleintiere. 2013;4:229-36.

44. Connor JE. Science-based medicine: what are the application barriers? In: AASV 2011 annual meeting. Phoenix, Arizona: American Association of Swine Veterinarians; 2011. p. 23-32.

45. Grimshaw JM. A knowledge synthesis chapter [internet]. Ottawa; 2010. Available from: http://cihr-irsc.gc.ca/e/41382.html.

46. Cooper H, Hedges LV. Research synthesis as a scientific process. In: Cooper $H$, Hedges LV, Valentine JC, editors. The handbook of research synthesis and meta-analysis. Second. New York: Russell Sage Foundation; 2009. p. 3-16.

47. Tricco AC, Tetzlaff J, Moher D. The art and science of knowledge synthesis. J Clin Epidemiol. 2011;64(1):11-20. https://doi.org/10.1016/j.jclinepi.2009.11.007.

48. Sargeant JM, Elgie R, Valcour J, Saint-Onge J, Thompson A, Marcynuk P, et al. Methodological quality and completeness of reporting in clinical trials conducted in livestock species. Prev Vet Med. 2009;91(2-4):107-15.

49. Waddell L, Rajić A, Sargeant J, Parker S, Deckert A, McEwen S. The methodological soundness of literature reviews addressing three potential zoonotic public health issues. Zoonoses Public Health. 2009; 56(9-10):477-89.

50. O'Connor A, Sargeant J. Research synthesis in veterinary science: narrative reviews, systematic reviews and meta-analysis. Vet J. 2015;206(3):261-7. https://doi.org/10.1016/j.tvjl.2015.08.025.

51. Keay S, Poljak Z, Klapwyk M, O'Connor A, Friendship RM, O'Sullivan TL, et al. Influenza A virus vaccine research conducted in swine from 1990 to May 2018: A scoping review. PLoS One. 2020;15(7):e0236062. https://doi.org/10. 1371/journal.pone.0236062.

52. Platt B, Hawton K, Simkin S, Mellanby RJ. Suicidal behaviour and psychosocial problems in veterinary surgeons: a systematic review. Soc Psychiatry Psychiatr Epidemiol. 2012;47(2):223-40.

53. Nielsen TD, Dean RS, Massey A, Brennan ML. Survey of the UK veterinary profession 2: Sources of information used by veterinarians. Vet Rec. 2015; 177(7). https://doi.org/10.1136/vr.103068.

54. Wales T. Practice makes perfect? Vets' informatoin seeking behaviour and informatoin use explored. ASLIB Proc. 2000;52(7):235-46.

55. O'Connor AM, Sargeant JM. Meta-analyses including data from observational studies. Prev Vet Med. 2014;113(3):313-22. https://doi.org/10. 1016/j.prevetmed.2013.10.017.

56. Dohoo IR. Bias-is it a problem, and what should we do? Prev Vet Med. 2014; 113(3):331-7. https://doi.org/10.1016/j.prevetmed.2013.10.008.

57. Martin W. Making valid causal inferences from observational data. Prev Vet Med. 2014;113(3):281-97. https://doi.org/10.1016/j.prevetmed.2013.09.006.

58. Sargeant JM, O'Connor AM, Renter DG, Kelton DF, Snedeker K, Wisener LV, et al. Reporting of methodological features in observational studies of preharvest food safety. Prev Vet Med. 2011;98(2-3):88-98. Available from: https://doi.org/10.1016/j.prevetmed.2010.10.009.

59. Sargeant JM, O'Connor AM, Dohoo IR, Erb HN, Cevallos M, Egger M, et al. Methods and processes of developing the strengthening the reporting of observational studies in epidemiology - veterinary (STROBE-vet) statement. J Food Prot. 2016;79(12):2211-9 Available from: http://jfoodprotection.org/ doi/10.4315/0362-028X.JFP-16-016.

60. Farrington CP. On vaccine efficacy and reproduction numbers. Math Biosci. 2003;185(1):89-109.

61. Ridenhour B, Kowalik JM, Shay DK. Unraveling R0: considerations for public health applications. Am J Public Health. 2014;104(2):32-41.

62. Shim E, Galvani AP. Distinguishing vaccine efficacy and effectiveness. Vaccine. 2012;30(47):6700-5 Available from: http://www.sciencedirect.com/ science/article/pii/S0264410X12012388. 
63. Grimes DA, Schulz KF. Bias and ausal associations in observational research. Lancet. 2002;359:248-52.

64. O'Connor AM, Sargeant JM. Critical appraisal of studies using laboratory animal models. ILAR J. 2014;55(3):405-17.

65. Huntley SJ, Dean RS, Massey A, Brennan ML. International evidence-based medicine survey of the veterinary profession: information sources used by veterinarians. PLoS One. 2016;11(7):1-18. https:/doi.org/10.1371/journal.pone.0159732.

66. Arlt SP, Haimerl P, Heuwieser W. Training evidence-based veterinary medicine by collaborative development of critically appraised topics. J Vet Med Educ. 2012;39(2):111-8 Available from: http://jvme.utpjournals.press/ doi/10.3138/jvme.1111.112R.

67. Vandeweerd JM, Clegg P, Buczinski S. How can Veterinarians Base their medical decisions on the best available scientific evidence? Vet Clin North Am - Food Anim Pract. 2012;28(1):1-11.

68. Holmes MA. Philosophical foundations of evidence-based medicine for veterinary clinicians. J Am Vet Med Assoc. 2009;235(9):1035-9 Available from: http://avmajournals.avma.org/doi/abs/10.2460/javma.235.9.1035.

69. Yousefi-Nooraie R, Rashidian A, Keating JL, Schonstein E. Teaching evidencebased practice: the teachers consider the content. J Eval Clin Pract. 2007; 13(4):569-75.

70. Patelarou A, Kyriakoulis KG, Stamou AA, Laliotis A, Sifaki-Pistolla D, Matalliotakis $M$, et al. Approaches to teach evidence-based practice among health professionals: an overview of the existing evidence. Adv Med Educ Pract. 2017:8:455-64 Available from: https://www.dovepress.com/ approaches-to-teach-evidence-based-practice-among-health-professionalspeer-reviewed-article-AMEP.

71. Schmidt PL. Evidence-based veterinary medicine: evolution, revolution, or repackaging of veterinary practice? Vet Clin North Am - Small Anim Pract. 2007;37(3):409-17.

72. Fosgate GT. Veterinary student and veterinarian attitudes toward veterinary public health and epidemiology. J Am Vet Med Assoc. 2008;233(2):240-7. https://doi.org/10.2460/javma.233.2.240.

73. Armijo-Olivo S, Stiles CR, Hagen NA, Biondo PD, Cummings GG. Assessment of study quality for systematic reviews: a comparison of the Cochrane collaboration risk of Bias tool and the effective public health practice project quality assessment tool: methodological research. J Eval Clin Pract. 2012;18(1):12-8.

74. da Costa BR, Beckett B, Diaz A, Resta NM, Johnston BC, Egger M, et al. Effect of standardized training on the reliability of the Cochrane risk of bias assessment tool: a prospective study. Syst Rev. 2017:6(1):4-11.

75. Dowker A, Sarkar A, Looi CY. Mathematics anxiety: What have we learned in 60 years? Front Psychol. 2016;7. https://doi.org/10.3389/fpsyg.2016.00508.

76. Zeimet R, Kreienbrock L, Doherr MG. Teaching biostatistics and epidemiology in the veterinary curriculum: what do our fellow lecturers expect? J Vet Med Educ. 2015;42(1):53-65 Available from: http://jvme. utpjournals.press/doi/10.3138/jvme.0314-029R2.

77. Nakagawa S, Samarasinghe G, Haddaway NR, Westgate MJ, O'Dea RE, Noble DWA, et al. Research weaving: visualizing the future of research synthesis. Trends Ecol Evol. 2019;34(3):224-38. https://doi.org/10.1016/j.tree.2018.11.007.

78. Kreuter MW, Bernhardt JM. Reframing the dissemination challenge: a marketing and distribution perspective. Am J Public Health. 2009;99(12): 2123-7.

79. Dobbins M, Jack S, Thomas H, Kothari A. Public health Decisoin-makers' informational needs and preferences for receiving research evidence. Worldviews Evidence-Based Nurs. 2007:4(3):156-63.

80. Young I, Kerr A, Waddell L, Pham MT, Greig J, McEwen SA, et al. A guide for developing plain-language and contextual summaries of systematic reviews in Agri-food public health. Foodborne Pathog Dis. 2014;11(12):930-7.

81. Gagnon ML. Moving knowledge to action through dissemination and exchange. J Clin Epidemiol. 2011;64(1):25-31. https://doi.org/10.1016/j. jclinepi.2009.08.013.

82. Lau J, loannidis JP, Schmid CH. Summing up evidence: one answer is not always enough. Lancet. 1998;351(January):123-7.

83. Stirling A. Keep it complex: when knowledge is uncertain, experts should avoid pressures to simplify their advice. Nature. 2010;468(December):1029-31.

84. Ioannidis JPA. Why most published research findings are false. PLoS Med. 2005;2(8):0696-701.

85. Lavis JN. How can we support the use of systematic reviews in policymaking? PLoS Med. 2009;6(11):1-6.
86. Lavis JN, Robertson D, Woodside JM, McLeod CB, Abelson J. How can research organizations more effectively transfer research knowledge to decision makers? Milbank Q. 2003;81(2):221-48.

87. Wilson MG, Lavis JN, Travers R, Rourke SB. Community-based knowledge transfer and exchange: Helping community-based organizations link research to action. Implement Sci. 2010;5:33. https://doi.org/10.1186/17485908-5-33.

88. Brisson Y. The changing face of the Canadian hog industry. Canadian Agriculture at a Glance. Analytic Paper. [Internet]. Statistics Canada. Minister of Industry, Catalogue no. 96-325-x-No. 005. 2017 [cited 2017 Sep 9]. Available from: http://www.statcan.gc.ca/pub/96-325-x/2014001/article/1402 7-eng.htm.

89. USDA. USDA Census of Agriculture 2012. Hogs and Pig Farming. [Internet]. Census of Agriculture 2012. 2012. Available from: https://quickstats.nass. usda.gov/results/A3DB68A8-5219-390A-BFCA-9A37A47BD6E0. Accessed 21 Oct 2020.

90. AASV. American Association of Swine Veterinarians 2016 Membership directory. Perry, IA: American Association of Swine Veterinarians; 2016.

91. Tavakol M, Dennick R. Making sense of Cronbach's alpha. Int J Med Educ. 2011;2:53-5.

92. Larson RL, White BJ. Importance of the role of the scientific literature in clinical decision making. JAVMA. 2015;247(1):58-64.

\section{Publisher's Note}

Springer Nature remains neutral with regard to jurisdictional claims in published maps and institutional affiliations.

\section{Ready to submit your research? Choose BMC and benefit from:}

- fast, convenient online submission

- thorough peer review by experienced researchers in your field

- rapid publication on acceptance

- support for research data, including large and complex data types

- gold Open Access which fosters wider collaboration and increased citations

- maximum visibility for your research: over $100 \mathrm{M}$ website views per year

At BMC, research is always in progress.

Learn more biomedcentral.com/submissions 